\title{
Colombian Anopheles triannulatus (Diptera: Culicidae) Naturally Infected with Plasmodium spp.
}

\author{
Doris A. Rosero, ${ }^{1}$ Nelson Naranjo-Diaz, ${ }^{1}$ Natalí Alvarez, ${ }^{1}$ Astrid V. Cienfuegos, ${ }^{1}$ \\ Carolina Torres, ${ }^{2}$ Shirley Luckhart, ${ }^{3}$ and Margarita M. Correa ${ }^{1}$ \\ ${ }^{1}$ Grupo de Microbiología Molecular, Escuela de Microbiología, Universidad de Antioquia, Calle 67 53-108, Lab 5-430, \\ Medellín, Colombia \\ ${ }^{2}$ Linea de Entomología Médica, Programa de Estudio y Control de Enfermedades Tropicales (PECET), Universidad de Antioquia, \\ Sede de Investigación Universitaria (SIU), Calle 62 no. 52-59, Lab 632, Medellín, Colombia \\ ${ }^{3}$ Department of Medical Microbiology and Immunology, University of California at Davis, Shields Avenue, Tupper Hall, \\ Room 3146, Davis, CA, USA
}

Correspondence should be addressed to Margarita M. Correa; margaritcorrea@gmail.com

Received 2 July 2013; Accepted 13 August 2013

Academic Editors: J. M. Rubio and P. Somboon

Copyright (C) 2013 Doris A. Rosero et al. This is an open access article distributed under the Creative Commons Attribution License, which permits unrestricted use, distribution, and reproduction in any medium, provided the original work is properly cited.

\begin{abstract}
The role of Anopheles triannulatus as a local vector has not yet been defined for malaria-endemic regions of Colombia. Therefore, the aim of this work was to detect An. triannulatus naturally infected with Plasmodium spp., as an approximation to determining its importance as malaria vector in the country. A total of $510 \mathrm{An}$. triannulatus were collected in six malaria-endemic localities of NW and SE Colombia from January 2009 to March 2011. In the NW, two specimens were naturally infected; one with Plasmodium vivax VK247, collected biting on humans and the other with Plasmodium falciparum, collected resting on cattle. In the SE, two specimens were positive for $P$. falciparum. Although these results show An. triannulatus naturally infected with Plasmodium, further studies are recommended to demonstrate the epidemiological importance of this species in malaria-endemic regions of Colombia.
\end{abstract}

\section{Introduction}

Malaria is an important public health problem in Colombia with approximately $60 \%$ of the territory being suitable for disease transmission [1]. In 2010, 116,914 malaria cases were reported [2], for an annual parasite index (API) of 11.58/1,000 inhabitants, and in 2011, only 62,969 cases were reported for API of 6.2/1,000 inhabitants [3], although underregistration of cases is presumed [4]. The Urabá-Bajo Cauca and Alto Sinú (UCS) epidemiological region, NW Colombia, registers near $60 \%$ of the total malaria cases of the country and the Amazonas region, SE, $0.67 \%[2,5]$.

In Colombia, based on epidemiological, entomological or parasite detection records, at least nine Anopheles species have been incriminated as malaria vectors. Three are of primary importance: Anopheles (Nyssorhynchus) albimanus Wiedemann 1920, Anopheles (Nys.) darlingi Root 1926, and Anopheles (Nys.) nuneztovari Gabaldón 1940, and six other species have relevance as secondary or local vectors [6-9].
However, there are species that in neighboring countries have been incriminated as local or regional vectors, but their role in transmission is not yet established for Colombia [1]. This is the case of Anopheles (Nys.) triannulatus Neiva and Pinto 1922, a species widely distributed in the country [10]. Interestingly, in Cimitarra municipality, NE Colombia, it was the most abundant species collected and had an indoor biting behavior similar to the main vector, An. nuneztovari [11]. Also, in Santa Rosa de Lima, Bolivar, in northern Colombia, An. triannulatus was the predominant species, found in sympatry with the primary malaria vector An. albimanus [9]. Furthermore, in localities of the Amazon Region, SE Colombia, it was collected in peridomestic areas showing anthropophilic activity and in sympatry with the main vectors An. darlingi and An. nuneztovari [12]. Despite the preferentially zoophilic behavior reported for An. triannulatus in Brazil [13, 14], Colombia [9], and Venezuela [15], this species is suggested to play a role in malaria transmission as a secondary vector [16], especially, if it is in 


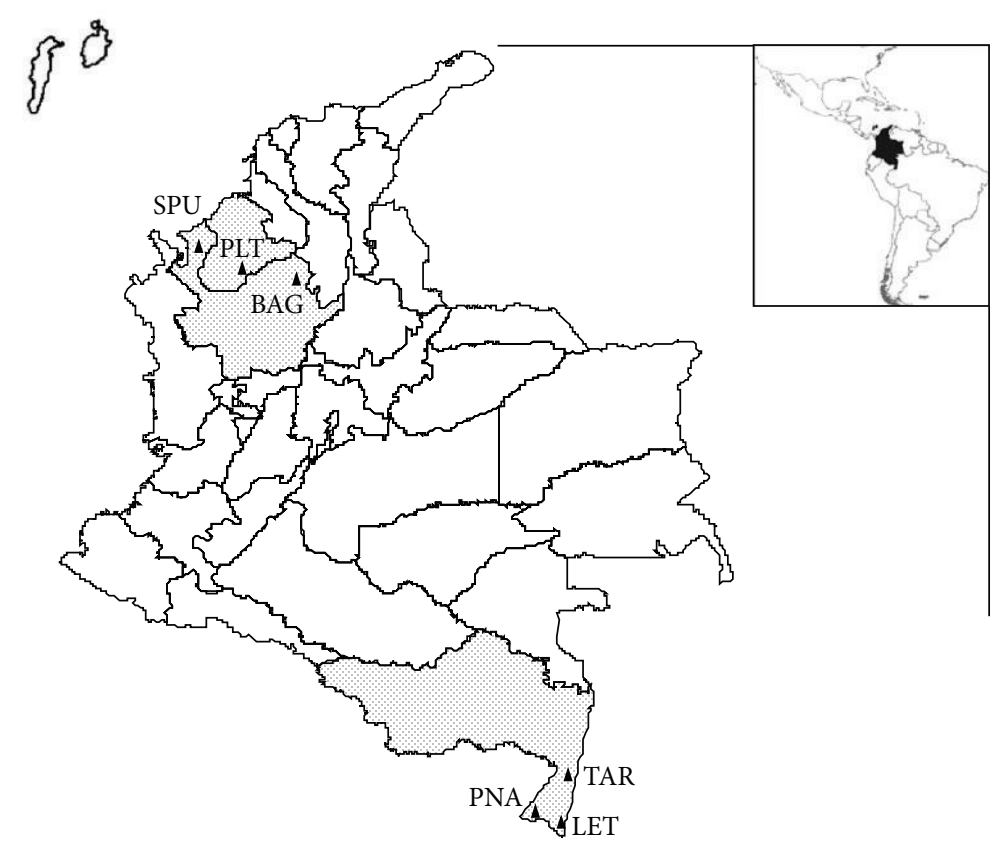

FIGURE 1: Localities of NW and SE Colombia where Anopheles triannulatus were collected. Puerto Libertador-PLT in Córdoba, El Bagre-BAG and San Pedro de Urabá-SPU in Antioquia, Tarapacá-TAR, Leticia-LET, and Puerto Nariño-PNA in Amazonas Department.

high densities [17], behaving as an opportunistic species depending on host availability and abundance [18]. In Brazil, An. triannulatus has been detected infected with Plasmodium vivax Grassi and Felleti 1890, in Pará State [18], Rondônia State [19, 20] and Amazonas State [21], with Plasmodium falciparum Welch 1897 and Plasmodium malariae Laveran 1880 in Amazonas [21] and Amapá State [17]. In other South American countries, An. triannulatus was reported as the dominant vector in eastern Loreto Department, Perú [22] and in Bolivia, and it is suggested to be a secondary vector [23, 24]. According to older reports, in Venezuela, An. triannulatus was epidemiologically implicated as a vector during a malaria outbreak [25], and some years later detected with natural oocyst infection [26], being considered a potential vector in western Venezuela where it showed a more anthropophilic behavior than An. nuneztovari and An. oswaldoi [27]. In Colombia, several studies have evaluated An. triannulatus for Plasmodium infection, using salivary glands and midgut dissection [28, 29] or ELISA and PCR [7-9, 30]; however, only recently, this species was detected infected with Plasmodium vivax [30].

Anopheles triannulatus is considered a complex of at least three species, Anopheles triannulatus s.s. Neiva and Pinto 1922, Anopheles halophylus Silva-do-Nascimento and Lourenço-de-Oliveira 2002, and Anopheles triannulatus C $[14,31]$, that may differ in their vectorial capacity and involvement in parasite transmission $[32,33]$. Up to the present, An. halophylus and An. triannulatus $\mathrm{C}$ have not been incriminated in malaria transmission $[14,31]$. In Colombia, there is no evidence for the existence of more than one species of the Triannulatus Complex. Only a recent study found a substantial genetic division, with two An. triannulatus lineages, NW and SE, coinciding with their geographical distributions in Colombia [34]. Consecutively, An. triannulatus NW lineage was detected infected with $P$. vivax in the NW [30]. This finding motivated a more comprehensive assessment of An. triannulatus parasite infection, through the evaluation of specimens collected in six localities of two malaria endemic regions, the Urabá-Bajo Cauca and Alto Sinú, NW, and the Amazonas region, SE Colombia.

\section{Materials and Methods}

2.1. Mosquito Collection and Processing. Anopheles triannulatus specimens were collected from January 2009 to March 2011 in six Colombian localities (Figure 1). These localities were selected based on the reports of malaria cases and An. triannulatus presence. The municipalities of LeticiaLET, Puerto Nariño-PNA, and Tarapacá-TAR in Amazonas Department, account for $70 \%$ of the malaria cases reported in the Amazonian region [35]. Antioquia and Córdoba Departments in the UCS region, NW, reported $>60 \%$ of total number of malaria cases of the country in 2010 [2, 5]. Of these, three municipalities in Cordoba (Tierralta, Montelíbano, and Puerto Libertador) contributed with $18 \%$ and three in Antioquia (Bagre, Caceres and Zaragoza) with $42 \%$ of those cases [5]. Available data for some of the localities indicate that, in 2010 Bagre-BAG reported 14,258 cases and San Pedro de Urabá-SPU 1,040 [36]. Indoor and outdoor collections (within $\sim 10 \mathrm{~m}$ of each house), from 18:00 to 24:00 $\mathrm{h}$ and at least one overnight (18:00-06:00 h) collection per field trip were performed, using human-landing catches under an informed consent agreement and collection protocol reviewed and approved by a University of Antioquia Institutional Review Board (Comité de Bioética Sede Investigación Universitaria, CBEIH-SIU, UdeA, approval document 
07-41-082). In addition, in SPU and Puerto Libertador (PLT), $\mathrm{NW}$, mosquitoes resting on cattle were collected in nearby corrals (within $\sim 10$ to $100 \mathrm{~m}$ from the house). At SE localities specimens were provided by trained personnel by means of a contract for mosquito collections, and only peridomestic collections from 18:00 to $23: 00 \mathrm{~h}$ were conducted. All Anopheles specimens were identified based on morphological features [10]. Also, the species assignation for specimens with problematic morphology and for all An. triannulatus was confirmed by a PCR-RFLP-ITS2 assay [37, 38], and MegaBLAST of An. triannulatus COI sequences, accession numbers JX852142-JX852282 [34].

2.2. Detection of Anopheles triannulatus Naturally Infected with Plasmodium spp. The An. triannulatus specimens processed by Enzyme-linked immunosorbent assay (ELISA) were tested in pools of five head-thoraces grouped by collection date and locality. Detection of the circumsporozoite (CSP) protein specific for $P$. falciparum and P. vivax variants VK247 and VK210 was carried out in separate plates following procedures optimized by personnel of the Molecular Microbiology Group [8, 9]. ELISA positive specimens were those giving an OD result (WL: $405 \mathrm{~nm}$ ) equal or above the cut off value, set as twice the mean of seven negative controls run consecutively in each plate. Positive pools were evaluated in a second ELISA, performed at a later date to reduce the chance of reporting false positives [9, 39]. Positive controls were those supplied with the ELISA test reagents. Lysates prepared from colonized An. albimanus served as negative controls.

For the nested PCR, DNA was extracted from individual abdomens following a salt precipitation protocol [40]. Amplifications using genus and species-specific primers designed to amplify the Plasmodium small ribosomal subunit DNA were performed using the primers and conditions previously described [41], with six $\mu \mathrm{L}$ of extracted DNA used as template in a $25 \mu \mathrm{L}$ reaction mixture. For the genus nest- 2 and the Plasmodium species-specific amplifications, six $\mu \mathrm{L}$ of the previous amplification product served as the DNA template. Plasmodium vivax DNA was used as the positive control. Specimens with a positive nested PCR and ELISA result were further confirmed for Plasmodium infection using a PCR directed to detect a mitochondrial cytochrome b (Cytb) fragment specific for human Plasmodium spp. [42], using two $\mu \mathrm{L}$ of extracted DNA as the template.

2.3. Data Analysis. Mosquito infection rates (IRs), or the percentage of Plasmodium infected An. triannulatus, were calculated as the number of positive An. triannulatus (np) per number of total analyzed (nt) per $100[\mathrm{IR}=(\mathrm{np} / \mathrm{nt}) \times$ 100] [43]. The confidence interval (CI: 95\%) was calculated to indicate the reliability of the estimated value using the EPIDAT program version 3.1 [44].

\section{Results}

3.1. Anopheles triannulatus Abundance. Of a total of 510 An. triannulatus collected, 210 were from northwestern localities (Table 1). In BAG locality, 87 An. triannulatus were collected in four field trips and approximately $162 \mathrm{~h}$ of sampling, being the third most abundant species during the August and December 2009 collections (12\% and 3\%, resp.), after An. darlingi and An. nuneztovari (Table 1). In SPU, 39 An. triannulatus were collected during two field trips and $72 \mathrm{~h}$ of sampling. Here, it was also the third most abundant species (2\%), after An. darlingi and An. nuneztovari in the February 2010 collection, and after An. nuneztovari and Anopheles (Anopheles) punctimacula s.l. in March 2011 (18\%) (Table 1). It is worth noting that in PLT, after four collections with $168 \mathrm{~h}$ of sampling, An. triannulatus was only detected in the June 2010 collection, being the second most abundant species (28\%) after An. nuneztovari (Table 1). Data on abundance and entomological parameters for other species collected in NW localities are available in [30].

In SE, a total of 300 An. triannulatus specimens were collected by HLC. In LET, 86 An. triannulatus were collected in two sites and approximately $15 \mathrm{~h}$ of sampling, being the most predominant species in both sites (63\% and $80 \%)$ (Table 2). In PNA, 89 An. triannulatus were collected in three sites, during $60 \mathrm{~h}$ of sampling. This species was the predominant species during three samplings conducted in Puerto Rico site, PNA (58\%, 97\% y 83\%) (Table 2). In TAR, 125 An. triannulatus were collected in six sites and $95 \mathrm{~h}$ of sampling. Remarkably, in San Sebastian, TAR, it was the second most abundant species (13\%) after An. darlingi in the June 2010 collection and became the most predominant species (90\%) during the October 2010 collection. However, in TAR, An. darlingi was the predominant species in the rest of the collections (Table 2).

3.2. Anopheles triannulatus Infection by Plasmodium spp. In NW, two An. triannulatus specimens were detected with Plasmodium infection (Table 3), one in BAG infected with $P$. vivax VK247, as detected by only the first ELISA and the nested PCRs (Plasmodium and species-specific amplifications, IR = 1.51, CI: $0.04-8.15)$. This specimen was collected by HLC, indoors, between 18:00 to 19:00 h, during the January 2009 collection when An. triannulatus was found in low abundance (2\%) (Table 1). In this locality, the main vector species were also detected infected: An. nuneztovari with $P$. vivax VK247 $(\mathrm{IR}=0.10, \mathrm{CI}: 0.003-0.559)$ and An. darlingi with $P$. vivax VK210 (IR = 0.087, CI: 0.002-0.485) [30]. Another An. triannulatus was detected infected with $P$. falciparum in PLT, NW, as determined by the nested PCRs, Plasmodium and species-specific amplifications (Figure 2(a)) and Cytb PCR (Figure 2(b)) $(\mathrm{IR}=1.20$; CI: 0.03-6.53); however, an ELISA positive result was not obtained (Table 3 ). This specimen was collected between 21:00 to 22:00 h, resting on cattle kept in corrals in proximity to the collection site.

In SE, two An. triannulatus collected by HLC were positive for P. falciparum, as detected by only the first ELISA, result that was confirmed by the nested genus-specific PCR (detects Plasmodium), however, the species-specific nested PCR or the Cytb PCR were negative (Table 3). One of the infected An. triannulatus was collected in Puerto Rico site, PNA (IR = 1.20, CI: 0.03-6.53), during the August 2010 sampling, when An. triannulatus was the most abundant species (97\%) (Table 2). The other infected specimen (IR 


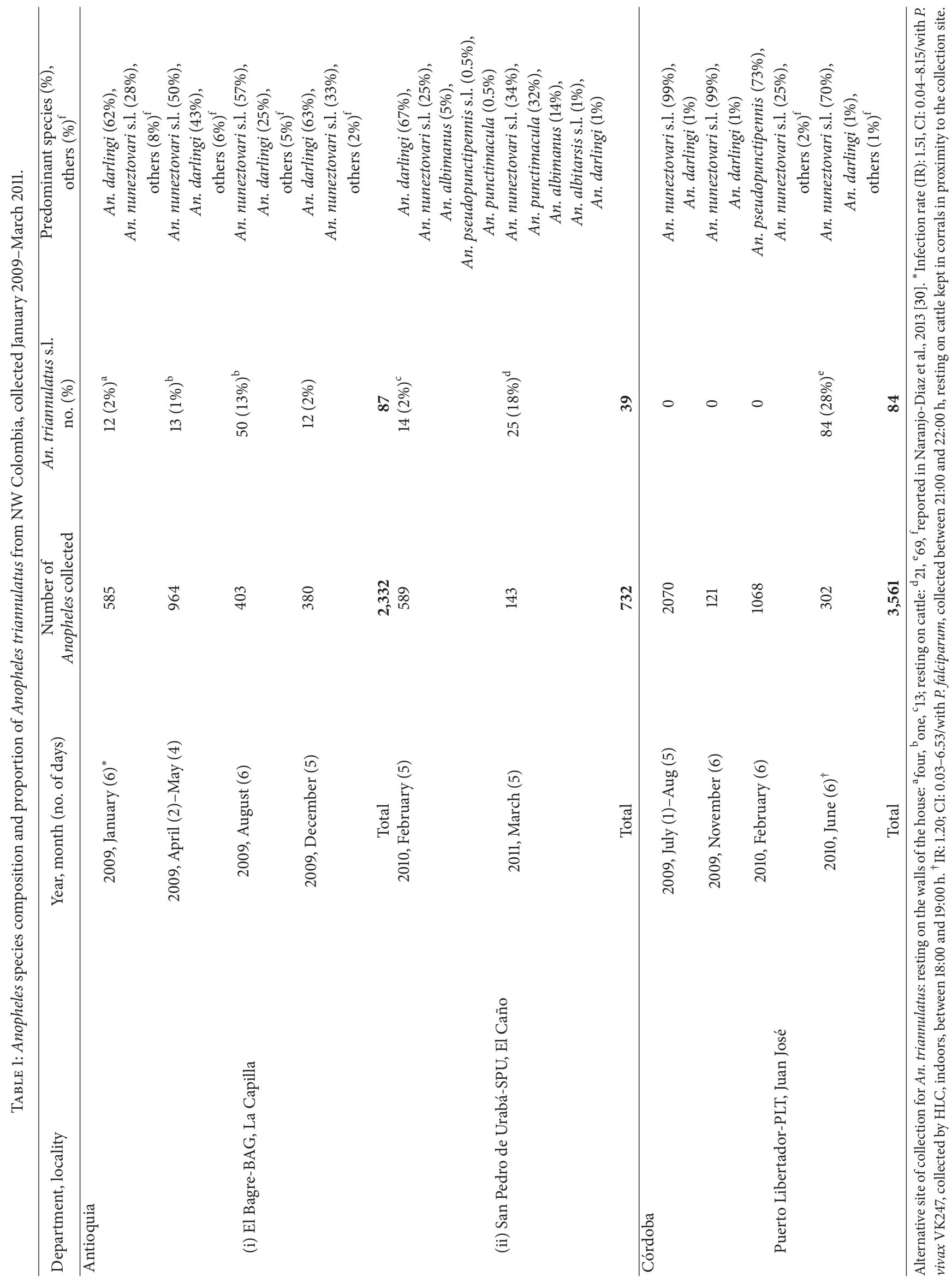




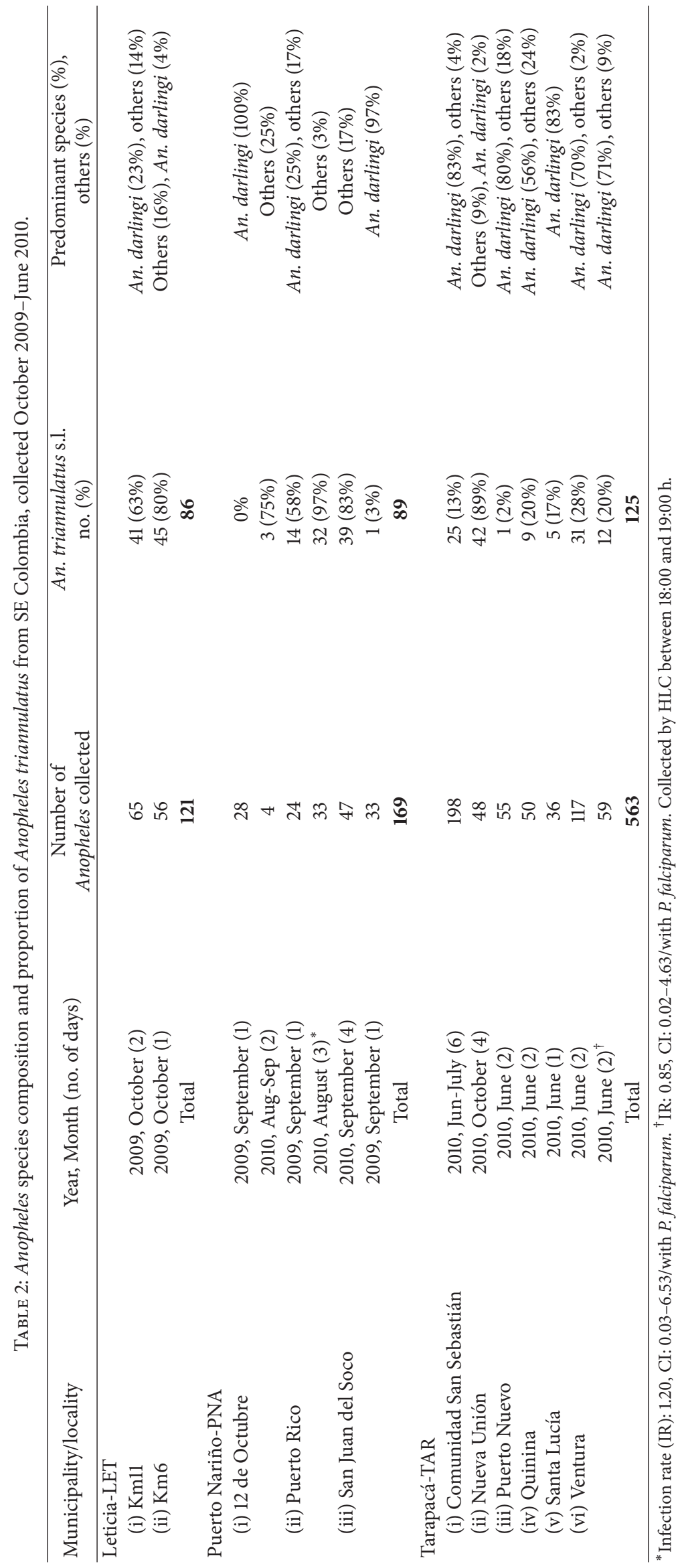


TABLE 3: Natural infection on Anopheles triannulatus from Northwestern and Southeastern Colombia.

\begin{tabular}{|c|c|c|c|c|c|c|}
\hline \multirow[b]{2}{*}{ Region/locality/collection site } & \multirow{2}{*}{$\begin{array}{c}\text { No. of } \\
\text { An. triannulatus } \\
\text { analyzed }\end{array}$} & \multirow[b]{2}{*}{$\begin{array}{c}\text { Plasmodium species }{ }^{\mathrm{a}} \text { : } \\
\text { infection rates }{ }^{\mathrm{b}}(95 \% \text { CI })\end{array}$} & \multicolumn{2}{|c|}{ ELISA test } & \multicolumn{2}{|c|}{ PCR } \\
\hline & & & First & $\begin{array}{c}\text { Second } \\
\text { (confirmation) }\end{array}$ & Nested & Cytb \\
\hline \multicolumn{7}{|l|}{ NW } \\
\hline El Bagre-BAG, La Capilla & 82 & $\begin{array}{c}P v \mathrm{VK} 247: \\
1.51(0.04-8.15)\end{array}$ & Positive & Negative & Positive & Negative \\
\hline Puerto Libertador-PLT, Juan José & 83 & Pf: $1.20(0.03-6.53)$ & Negative & Negative & Positive & Positive \\
\hline \multicolumn{7}{|l|}{ SE } \\
\hline Puerto Nariño (PNA), Puerto Rico & 83 & $P f: 1.20(0.03-6.53)$ & Positive & Negative & Positive* $^{*}$ & Negative \\
\hline Tarapaca (TAR), Ventura & 118 & Pf: $0.85(0.02-4.63)$ & Positive & Negative & Positive $^{*}$ & Negative \\
\hline
\end{tabular}

The table shows only results for those localities where naturally infected An. triannulatus were detected. ${ }^{a}$ Plasmodium species: PvVK247-P. vivax VK247, PvVK210-P. vivax VK210, Pf: P. falciparum. ${ }^{\mathrm{b}}$ Number of positive An. triannulatus (np) per number of total analyzed (nt) per 100, determined for each locality, $(\mathrm{IR}=(\mathrm{np} / \mathrm{nt}) \times 100) .{ }^{*}$ Positive result only in the nested PCR that detects Plasmodium genus, negative in the nested PCR that detects Plasmodium species. Due to the limitations on the available tests for detecting naturally infected anopheline mosquitoes (see discussion), positive specimens were determined as those given a positive result in at least two of the tests.

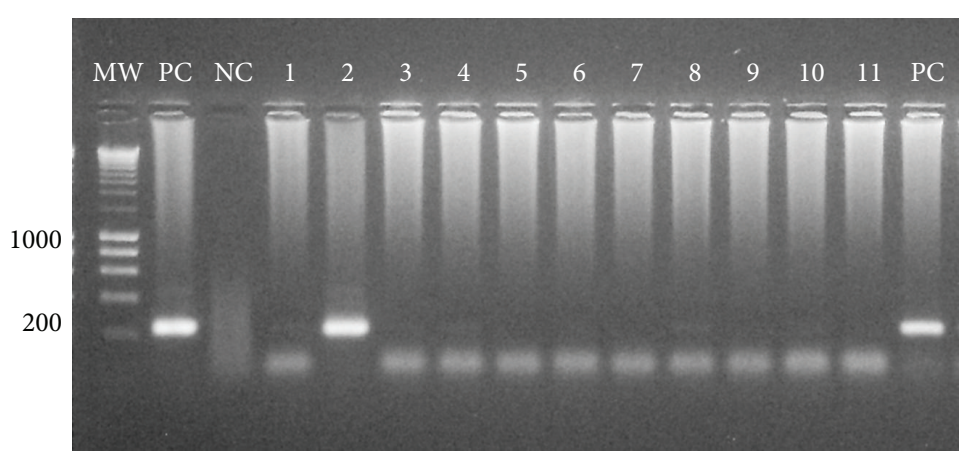

(a)

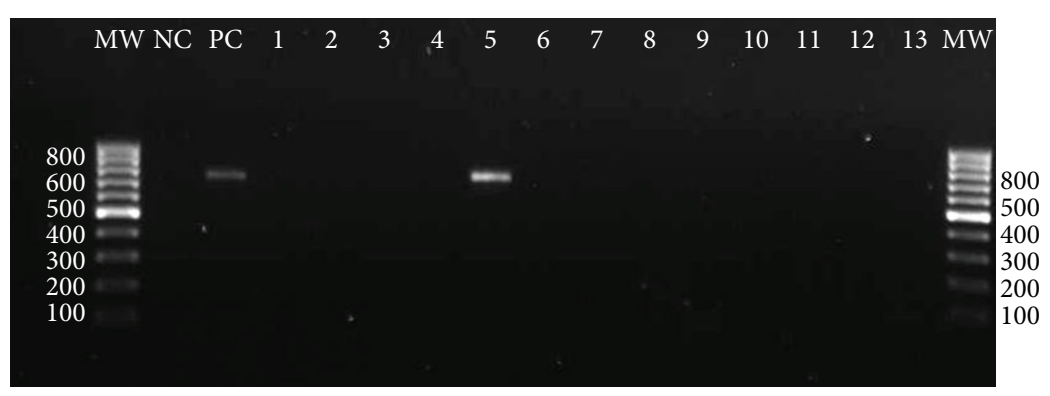

(b)

Figure 2: Nested and Cytb PCRs for Plasmodium detection in An. triannulatus. One \% agarose gel. Lanes: MW: molecular weight, PC: Positive control-Plasmodium vivax DNA, NC: negative control (no DNA). (a). Plasmodium genus-specific Nested PCR. 1-11: DNA from An. triannulatus from Puerto Libertador (PLT), (b). PCR-Cytb, 1-13: An. triannulatus from various localities. Lane 5: positive specimen from PLT, equivalent to sample in lane 2 of gel (a).

$=0.85$, CI: $0.02-4.63$ ) was collected in Ventura site, TAR, in June 2010, when An. triannulatus was the second most abundant species (20.3\%) (Table 2).

\section{Discussion}

The determination of parasite infection in anopheline mosquitoes is an important component for vector incrimination [45]. In Colombia, several studies have attempted to elucidate the role of An. triannulatus in transmission [79, 30], but, only recently, An. triannulatus NW linage [34] was reported infected with $P$. vivax VK247 [30]. In this study, a more thorough evaluation of An. triannulatus infection in specimens collected at various localities of malaria endemic areas of the country provided further evidence of Plasmodium-infected An. triannulatus. In BAG, NW, An. triannulatus collected biting in humans was generally in low abundance. In this locality, the specimen found infected had P. vivax [30], 
and the IR was of 1.51. The IRs for An. triannulatus infected with $P$. falciparum ranged from 0.85 to 1.20 . These IR values are similar or slightly higher than those found for the main Colombian vectors, An. albimanus in the Colombian Pacific region [9], and in the same locality, BAG, An. nuneztovari was detected infected with $P$. vivax VK247 and An. darlingi with $P$. vivax VK210 [30]. These IRs are also similar to the ones previously found for An. triannulatus in Brazil, where it was detected infected with the same Plasmodium species. For example, with P. vivax, IR was 0.5 [19] and 1.1 [20] in Rondônia State; with P. falciparum, IR was 0.8 in Amazonas State [21] and 0.13 in Amapá State [17]. However, in some sites of Brazil, higher IRs have been detected for An. triannulatus infected with $P$. vivax, of 8.9 in Pará State [18] and 3.7 in Amazonas State [21].

The infected An. triannulatus from BAG, NW, was collected indoors, which makes it even more important to further evaluate the epidemiological role of this species in this locality. Interestingly, a previous work in various localities of this region showed An. triannulatus with anthropophilic tendency and active indoors and outdoors [8]. However, the infected An. triannulatus collected resting on cattle in PLT, NW, suggests a zoophilic tendency, as previously documented for this species in this particular area, where one of the main economic activities is livestock production and the high availability of cattle may influence this feeding behavior [8]. The two specimens detected infected in PNA and TAR localities of the Amazonian region, SE Colombia, had $P$. falciparum. These infected specimens were collected in periods when An. triannulatus was the most or second most abundant species in PNA and TAR, constituting 97\% and $20 \%$ of the total collected specimens, respectively; notably in PNA, the primary vector An. darlingi was not detected in this collection period. This observation is similar to reports for An. triannulatus in localities of Pará, and Amazonas, Brazil, that indicate that this species colonized altered environments and became abundant and even dominated, outnumbering the main vector An. darlingi [21]. Of particular interest, PNA and TAR are in close proximity to LET (SE), a locality also included in a recent phylogeography study on An. triannulatus s.l. which evaluated specimens along the known geographic distribution of the species [46]. Of seven lineages proposed based on COI data, four were present in Colombia; particularly, lineage E, widely distributed in Brazil, where An. triannulatus s.l. has been found infected with Plasmodium spp. [17, 21], is also present in LET, SE; this makes it important to further investigate the role of An. triannulatus in transmission in these SE localities.

In this study, An. triannulatus was detected infected with both $P$. vivax and $P$. falciparum; however, only until recently this species was reported infected [30]. Among the reasons influencing the negative results could be that $A n$. triannulatus were at low abundance [8] or not being participating in transmission when collections were carried out. Moreover, laboratory experiments have indicated that An. triannulatus is less susceptible to salivary gland sporozoite infection than An. darlingi or other vectors [47]. Also, technical reasons can produce negative results; for example, in the case of low parasite infection in the mosquito, the ELISA could show false negative results because of the lower sensitivity of this technique as compared to the PCR [43, 48, 49]. Furthermore, negative results could originate from the specimen part used for the test in relation to the stage of the parasite cycle in the mosquito; for example, at the initial stage of sporogony when the sporozoites have not reached the salivary glands $[18,50]$, the CSP protein could be detected only in the midgut [51]. In the case of the PCR, interfering material present in the reaction and a low DNA concentration after extraction could produce a false negative result [52]. Likewise, false positive results of the test to detect Plasmodium-infected anophelines have been reported; specifically for the ELISA, when testing zoophilic mosquitoes [39]. Therefore, this should be a consideration when analyzing ELISA positive Plasmodium infection results in An. triannulatus, especially in NW localities where cattle is a main mosquito-feeding source. Therefore in this study, to avoid reporting false positive results, at least two positive tests of the ones performed (two ELISA reactions, Plasmodium genus and species-specific nested PCRs or Cytb PCR), served as criteria for defining Plasmodium infected Anopheles. In the case of the P. falciparum-infected An. triannulatus collected in cattle in PLT, NW, the positivity was determined by both nested and Cytb PCR. For the other infected specimens, a positive result was obtained in the first ELISA and confirmed by nested PCR. In accordance with our findings, variations in the results of the tests used to detect mosquito parasite infection have been reported in other studies [52, 53].

\section{Conclusions}

In this study, An. triannulatus was detected infected with both $P$. vivax and $P$. falciparum, which suggests the importance of further evaluating the epidemiological importance of this species in malaria endemic regions of Colombia. In addition, differences in results between the PCR and ELISA advocate the need for assessing the degree of sensitivity and specificity of these two techniques. But even of greater priority is the evaluation or development of new, more accurate methodologies to test Plasmodium infection in the Anopheles mosquitoes. In this sense, the novel PCR based on parasite Cytb sequences [42], rapid test as the VecTestTM dipstick assay $[54,55]$, and real-time PCR amplification [56, 57] deserve further evaluation. While this is done and given the limitations still found when using the available methodologies, it is recommended that at least two positive tests be used as the criterion for defining Plasmodium infection in wild collected Anopheles. This is of particular importance when investigating the role of presumptive vector species in disease transmission.

\section{Conflict of Interests}

The authors declare that they have no competing interests.

\section{Acknowledgments}

This work received funding from the National Institutes of Health NIH, USA, Project no. R03AI076710 and Estrategia 
para la Sostenibilidad de Grupos 2011-2012, no. E01624, to Margarita M. Correa; Comité para el Desarrollo de la Investigación-CODI-Universidad de Antioquia, project No. 8700-639, to Doris A. Rosero. The authors express their gratitude to M. Altamiranda and G. Gómez, who participated in specimen collection and identification and L. Jaramillo, for lab technical support.

\section{References}

[1] M. Arévalo-Herrera, M. L. Quiñones, C. Guerra et al., "Malaria in selected non-Amazonian countries of Latin America," Acta Tropica, vol. 121, no. 3, pp. 303-314, 2012.

[2] INS (Instituto Nacional de Salud), "Boletín Epidemiológico Semanal. Estadísticas del sistema de vigilancia en salud públicaSIVIGILA, Casos totales en la Semana Epidemiológica 52 y acumulados del año," Subdirección de Vigilancia y Control en Salud Pública, 2010, http://www.ins.gov.co/lineas-de-accion/ Subdireccion-Vigilancia/sivigila/Estadsticas\%20SIVIGILA/ SEMANA\%2052\%20DE\%202010.pdf.

[3] INS (Instituto Nacional de Salud), “Boletín Epidemiológico Semanal. Estadísticas del sistema de vigilancia en salud pública-SIVIGILA, Casos totales en la Semana Epidemiológica 52 y acumulados del año," Subdirección de Vigilancia y Control en Salud Pública, 2011, http://www.ins.gov.co/lineas-de-accion/ Subdireccion-Vigilancia/sivigila/Paginas/vigilancia-rutinaria .aspx.

[4] P. Chaparro, E. Soto, J. Padilla et al., "Estimación del subregistro de casos de paludismo en 10 municipios de la costa del Pacífico nariñense durante 2009," Biomédica, vol. 32, supplement, pp. 29-37, 2012.

[5] J. C. Rodríguez, G. A. Uribe, R. M. Araújo et al., "Epidemiology and control of malaria in Colombia," Memórias Do Instituto Oswaldo Cruz, vol. 106, supplement 1, pp. 114-122, 2011.

[6] V. Olano, H. Brochero, R. Saenz et al., "Mapas preliminares de la distribución de especies de Anopheles vectores de malaria en Colombia," Biomédica, vol. 21, pp. 402-408, 2001.

[7] M. L. Quiñones, F. Ruiz, D. A. Calle, R. E. Harbach, H. F. Erazo, and Y. Linton, "Incrimination of Anopheles (Nyssorhynchus) rangeli and $A n$. (Nys.) oswaldoi as natural vectors of Plasmodium vivax in Southern Colombia," Memórias do Instituto Oswaldo Cruz, vol. 101, no. 6, pp. 617-623, 2006.

[8] L. A. Gutiérrez, J. J. González, G. F. Gómez et al., "Species composition and natural infectivity of anthropophilic Anopheles (Diptera: Culicidae) in the states of Córdoba and Antioquia, Northwestern Colombia," Memórias Do Instituto Oswaldo Cruz, vol. 104, no. 8, pp. 1117-1124, 2009.

[9] L. A. Gutiérrez, N. Naranjo, L. M. Jaramillo et al., "Natural infectivity of Anopheles species from the Pacific and Atlantic Regions of Colombia," Acta Tropica, vol. 107, no. 2, pp. 99-105, 2008.

[10] R. González and N. Carrejo, Introducción al estudio taxonómico de Anopheles de Colombia: claves y notas de distribución, Programa Editorial Universidad del Valle, Cali, Colombia, 2nd edition, 2009.

[11] H. Brochero, P. X. Pareja, G. Ortiz, and V. A. Olano, "Breeding places and biting activity of Anopheles species in the municipality of Cimitarra, Santander, Colombia," Biomédica, vol. 26, no. 2, pp. 269-277, 2006.

[12] M. Rodríguez, L. Pérez, J. C. Caicedo et al., "Composition and biting activity of Anopheles (Diptera: Culicidae) in the Amazon region of Colombia," Journal of Medical Entomology, vol. 46, no. 2, pp. 307-315, 2009.

[13] T. F. Silva-do-Nascimento and R. Lourenço-de-Oliveira, "Diverse population dynamics of three Anopheles species belonging to the Triannulatus Complex (Diptera: Culicidae)," Memórias do Instituto Oswaldo Cruz, vol. 102, no. 8, pp. 975-982, 2007.

[14] T. F. Silva-Do-Nascimento, R. C. Wilkerson, R. Lourenço-DeOliveira, and F. A. Monteiro, "Molecular confirmation of the specific status of Anopheles halophylus (Diptera: Culicidae) and evidence of a new cryptic species within An. triannulatus in central Brazil," Journal of Medical Entomology, vol. 43, no. 3, pp. 455-459, 2006.

[15] J. E. Moreno, Y. Rubio-Palis, E. Páez, E. Pérez, and V. Sánchez, "Abundance, biting behaviour and parous rate of anopheline mosquito species in relation to malaria incidence in goldmining areas of southern Venezuela," Medical and Veterinary Entomology, vol. 21, no. 4, pp. 339-349, 2007.

[16] M. E. Sinka, Y. Rubio-Palis, S. Manguin et al., "The dominant Anopheles vectors of human malaria in the Americas: occurrence data, distribution maps and bionomic précis," Parasites and Vectors, vol. 3, article 72, 2010.

[17] A. K. R. Galardo, M. Arruda, A. A. R. D’Almeida Couto, R. Wirtz, L. P. Lounibos, and R. H. Zimmerman, "Malaria vector incrimination in three rural riverine villages in the Brazilian amazon," The American Journal of Tropical Medicine and Hygiene, vol. 76, no. 3, pp. 461-469, 2007.

[18] M. de Arruda, M. B. Carvalho, R. S. Nussenzweig, M. Maracic, A. W. Ferreira, and A. H. Cochrane, "Potential vectors of malaria and their different susceptibility to Plasmodium falciparum and Plasmodium vivax in Northern Brazil identified by immunoassay," The American Journal of Tropical Medicine and Hygiene, vol. 35, no. 5, pp. 873-881, 1986.

[19] J. de Oliveira-Ferreira, R. Lourenco-de-Oliveira, A. Teva, L. M. Deane, and C. T. Daniel-Ribeiro, "Natural malaria infections in anophelines in Rondônia state, Brazilian Amazon," The American Journal of Tropical Medicine and Hygiene, vol. 43, no. 1, pp. 6-10, 1990.

[20] L. M. Deane, C. D. Ribeiro, R. L. de Oliveira, J. Oliveira-Ferreira, and A. E. uimarães, "Study on the natural history of malaria in areas of the Rondônia State-Brazil and problems related to its control," Revista do Instituto de Medicina Tropical de São Paulo, vol. 30, no. 3, pp. 153-156, 1988.

[21] W. P. Tadei and B. D. Thatcher, "Malaria vectors in the Brazilian Amazon: Anopheles of the subgenus Nyssorhynchus," Revista do Instituto de Medicina Tropical de São Paulo, vol. 42, no. 2, pp. 87-94, 2000.

[22] J. Aramburu-Guarda, C. Ramal-Asayag, and R. Witzig, "Malaria reemergence in the Peruvian Amazon Region," Emerging Infectious Diseases, vol. 5, no. 2, pp. 209-215, 1999.

[23] H. Hiwat and G. Bretas, "Ecology of Anopheles darlingi root with respect to vector importance: a review," Parasites and Vectors, vol. 4, no. 1, pp. 177-189, 2011.

[24] S. Mollinedo and R. Mollinedo, "La malaria en Bolivia," Publicación Técnica No. 3, Ministerio de Salud y Prevision Social, Programa Nacional de Control de la Malaria, Red Nacional de Laboratorios de Salud, Unidad de Parasitología y Medio Ambiente, 2000.

[25] E. I. Benarroch, "Studies on malaria in Venezuela," The American Journal of Epidemiology, vol. 14, no. 3, pp. 690-693, 1931.

[26] A. Gabaldon and P. C. Garcia, "Zoogeografia de los anofelinos en Venezuela. I. Los dos vectores principales," Tijeretazos Sobre Malaria, vol. 10, no. 2, pp. 78-127, 1946. 
[27] Y. Rubio-Palis, C. F. Curtis, C. Gonzáles, and R. A. Wirtz, "Host choice of anopheline mosquitoes in a malaria endemic area of Western Venezuela," Medical and Veterinary Entomology, vol. 8, no. 3, pp. 275-280, 1994.

[28] M. A. Cadena, "Resultado de algunas disecciones de mosquitos," Revista de Higiene, vol. 20, p. 27, 1939.

[29] A. G. Galvis, "Biologia y distribución geográfica de los anofelinos en Colombia," Reimpreso de la Revista de la Facultad de Medicina, vol. 12, no. 2, p. 50, 1943.

[30] N. Naranjo-Diaz, D. A. Rosero, G. Rua-Uribe, S. Luckhart, and M. M. Correa, "Abundance, behavior and entomological inoculation rates of anthropophilic anophelines from a primary Colombian malaria endemic area," Parasites and Vectors, vol. 6, article 61, 2013.

[31] T. F. S. do Nascimento and R. Lourenco-de-Oliveira, "Anopheles halophylus, a new species of the subgenus nyssorhynchus (Diptera: Culicidae) from Brazil," Memórias do Instituto Oswaldo Cruz, vol. 97, no. 6, pp. 801-811, 2002.

[32] M. G. Rosa-Freitas, R. Lourenço-de-Oliveira, C. J. de CarvalhoPinto, C. Flores-Mendoza, and T. F. Silva-do-Nascimento, "Anopheline species complexes in Brazil. Current knowledge of those related to malaria transmission," Memórias do Instituto Oswaldo Cruz, vol. 93, no. 5, pp. 651-655, 1998.

[33] M. G. Rosa-Freitas, P. Tsouris, A. T. Peterson et al., "An ecoregional classification for the state of Roraima, Brazil. The importance of landscape in malaria biology," Memorias do Instituto Oswaldo Cruz, vol. 102, no. 3, pp. 349-357, 2007.

[34] D. A. Rosero, L. M. Jaramillo, L. A. Gutiérrez, J. E. Conn, and M. M. Correa, "Genetic diversity of Anopheles triannulatus s.l. (Diptera: Culicidae) from Northwestern and Southeastern Colombia," The American Journal of Tropical Medicine and Hygiene, vol. 87, no. 5, pp. 910-920, 2012.

[35] MPS (Ministerio de la Protección Social) and Dirección general de Salud Pública, "Control químico vector malaria rural mediante rociamiento de acción residual," Departamento Amazonas, Periodo informado año, 2010.

[36] DSSA (Direccion Seccional de Salud de Antioquia), "Incidencia de malaria total por municipios y regiones," 2010, http://www .dssa.gov.co/index.php/estadisticas/eventos-de-salud-publica.

[37] M. A. Zapata, A. V. Cienfuegos, O. I. Quirós, M. L. Quiñones, S. Luckhart, and M. M. Correa, "Discrimination of seven Anopheles species from San Pedro de Urabá, Antioquia, Colombia, by polymerase chain reaction-restriction fragment length polymorphism analysis of its sequences," The American Journal of Tropical Medicine and Hygiene, vol. 77, no. 1, pp. 67-72, 2007.

[38] A. V. Cienfuegos, D. A. Rosero, N. Naranjo, S. Luckhart, J. E. Conn, and M. M. Correa, "Evaluation of a PCR-RFLP-ITS2 assay for discrimination of Anopheles species in Northern and Western Colombia," Acta Tropica, vol. 118, no. 2, pp. 128-135, 2011.

[39] L. Durnez, W. van Bortel, L. Denis et al., "False positive circumsporozoite protein ELISA: a challenge for the estimation of the entomological inoculation rate of malaria and for vector incrimination," Malaria Journal, vol. 10, article 195, 2011.

[40] D. A. Rosero, L. A. Gutiérrez, A. V. Cienfuegos et al., "Optimización de un procedimiento de extracción de ADN para mosquitos anofelinos," Revista Colombiana de Entomología, vol. 36, no. 2, pp. 260-263, 2010.

[41] B. Singh, A. Bobogare, J. Cox-Singh, G. Snounou, M. S. Abdullah, and H. A. Rahman, "A genus- and species-specific nested polymerase chain reaction malaria detection assay for epidemiologic studies," The American Journal of Tropical Medicine and Hygiene, vol. 60, no. 4, pp. 687-692, 1999.

[42] A. U. Hasan, S. Suguri, J. Sattabongkot et al., "Implementation of a novel PCR based method for detecting malaria parasites from naturally infected mosquitoes in Papua New Guinea," Malaria Journal, vol. 8, article 182, 2009.

[43] J. C. Beier, P. V. Perkins, J. K. Koros et al., "Malaria sporozoite detection by dissection and ELISA to assess infectivity of afrotropical Anopheles (Diptera: Culicidae)," Journal of medical entomology, vol. 27, no. 3, pp. 377-384, 1990.

[44] M. I. Santiago, M. Lopez, E. Vazquez et al., "Epidat 3.1: Una herramienta INFORMÁTICA para el análisis epidemiológico de datos tabulados," in 6th Congreso Internacional de Informática en Salud, La Habana, Cuba, February 2007.

[45] J. C. Beier, "Malaria parasite development in mosquitoes," Annual Review of Entomology, vol. 43, pp. 519-543, 1998.

[46] M. Moreno, S. Bickersmith, W. Harlow et al., "Phylogeography of the neotropical Anopheles triannulatus complex (Diptera: Culicidae) supports deep structure and complex patterns," Parasites and Vectors, vol. 6, no. 1, article 47, 2013.

[47] T. A. Klein, J. B. P. Lima, M. S. Tada, and R. Miller, "Comparative susceptibility of anopheline mosquitoes in Rondonia, Brazil to infection by Plasmodium vivax," The American Journal of Tropical Medicine and Hygiene, vol. 45, no. 4, pp. 463-470, 1991.

[48] G. Snounou, S. Viriyakosol, X. P. Zhu et al., "High sensitivity of detection of human malaria parasites by the use of nested polymerase chain reaction," Molecular and Biochemical Parasitology, vol. 61, no. 2, pp. 315-320, 1993.

[49] A. Tassanakajon, V. Boonsaeng, P. Wilairat, and S. Panyim, "Polymerase chain reaction detection of Plasmodium falciparum in mosquitoes," Transactions of the Royal Society of Tropical Medicine and Hygiene, vol. 87, no. 3, pp. 273-275, 1993.

[50] S. Meister, A. C. Koutsos, and G. K. Christophides, "The Plasmodium parasite-a "new" challenge for insect innate immunity," International Journal for Parasitology, vol. 34, no. 13-14, pp. 1473-1482, 2004.

[51] N. Boulanger, Y. Charoenvit, A. Krettli, and B. Betschart, "Developmental changes in the circumsporozoite proteins of Plasmodium berghei and P. Gallinaceum in their mosquito vectors," Parasitology Research, vol. 81, no. 1, pp. 58-65, 1995.

[52] M. S. Alam, S. Chakma, W. A. Khan et al., "Diversity of anopheline species and their Plasmodium infection status in rural Bandarban, Bangladesh," Parasites and Vectors, vol. 5, article 150, 2012.

[53] J. A. M. da Rocha, S. B. de Oliveira, M. M. Póvoa, L. A. Moreira, and A. U. Krettli, "Malaria vectors in areas of Plasmodium falciparum epidemic transmission in the Amazon Region, Brazil," The American Journal of Tropical Medicine and Hygiene, vol. 78, no. 6, pp. 872-877, 2008.

[54] M. A. Appawu, K. M. Bosompem, S. Dadzie et al., "Detection of malaria sporozoites by standard ELISA and VecTest dipstick assay in field-collected anopheline mosquitoes from a malaria endemic site in Ghana," Tropical Medicine and International Health, vol. 8, no. 11, pp. 1012-1017, 2003.

[55] M. Moreno, J. Cano, S. Nzambo et al., "Malaria panel assay versus PCR: detection of naturally infected Anopheles melas in a coastal village of Equatorial Guinea," Malaria Journal, vol. 3, article 20, 2004.

[56] M. A. Rider, B. D. Byrd, J. Keating, D. M. Wesson, and K. A. Caillouet, "PCR detection of malaria parasites in desiccated 
Anopheles mosquitoes is uninhibited by storage time and temperature," Malaria Journal, vol. 11, article 193, 2012.

[57] C. Bass, D. Nikou, A. M. Blagborough et al., "PCR-based detection of Plasmodium in Anopheles mosquitoes: a comparison of a new high-throughput assay with existing methods," Malaria Journal, vol. 7, article 177, 2008. 

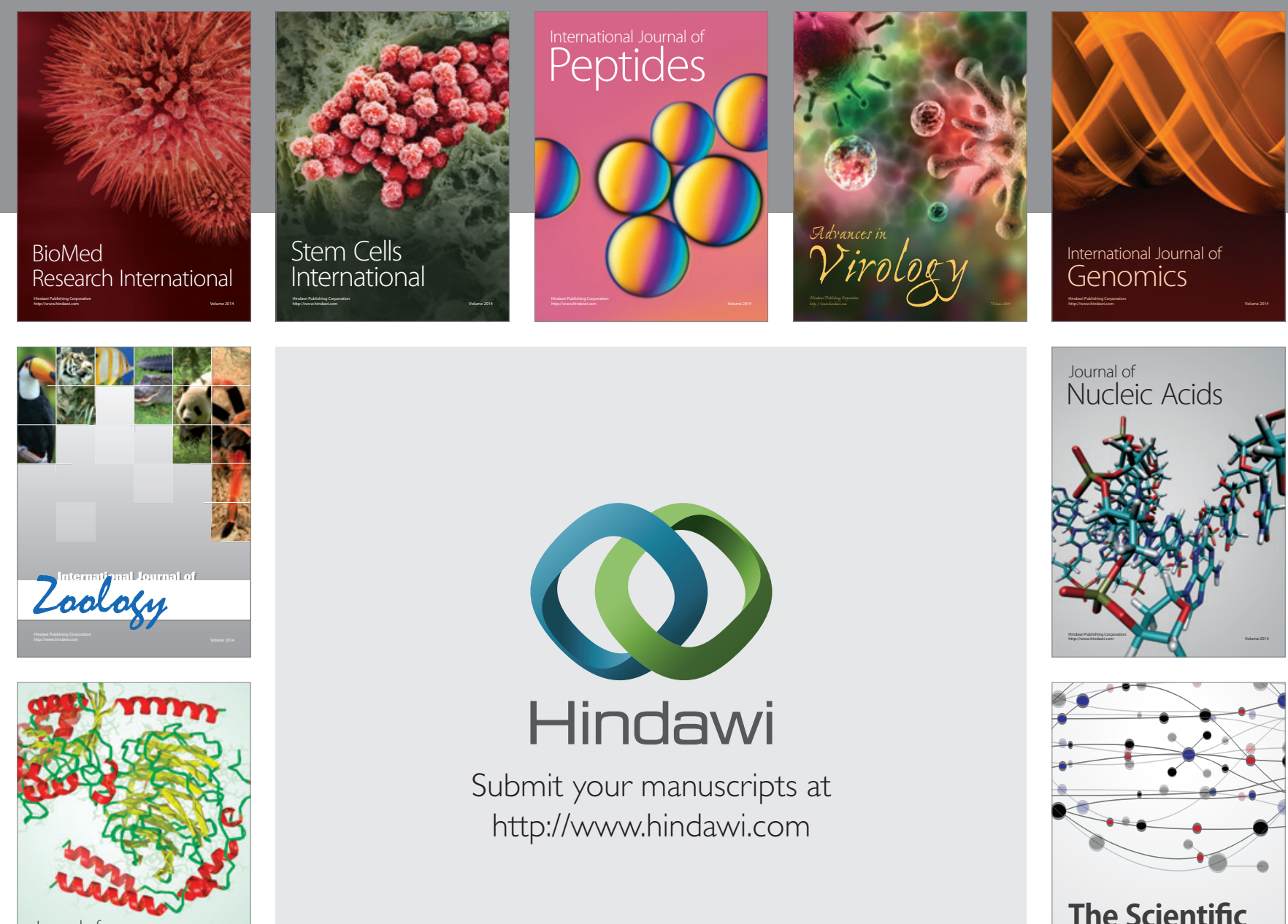

Submit your manuscripts at

http://www.hindawi.com

Journal of
Signal Transduction
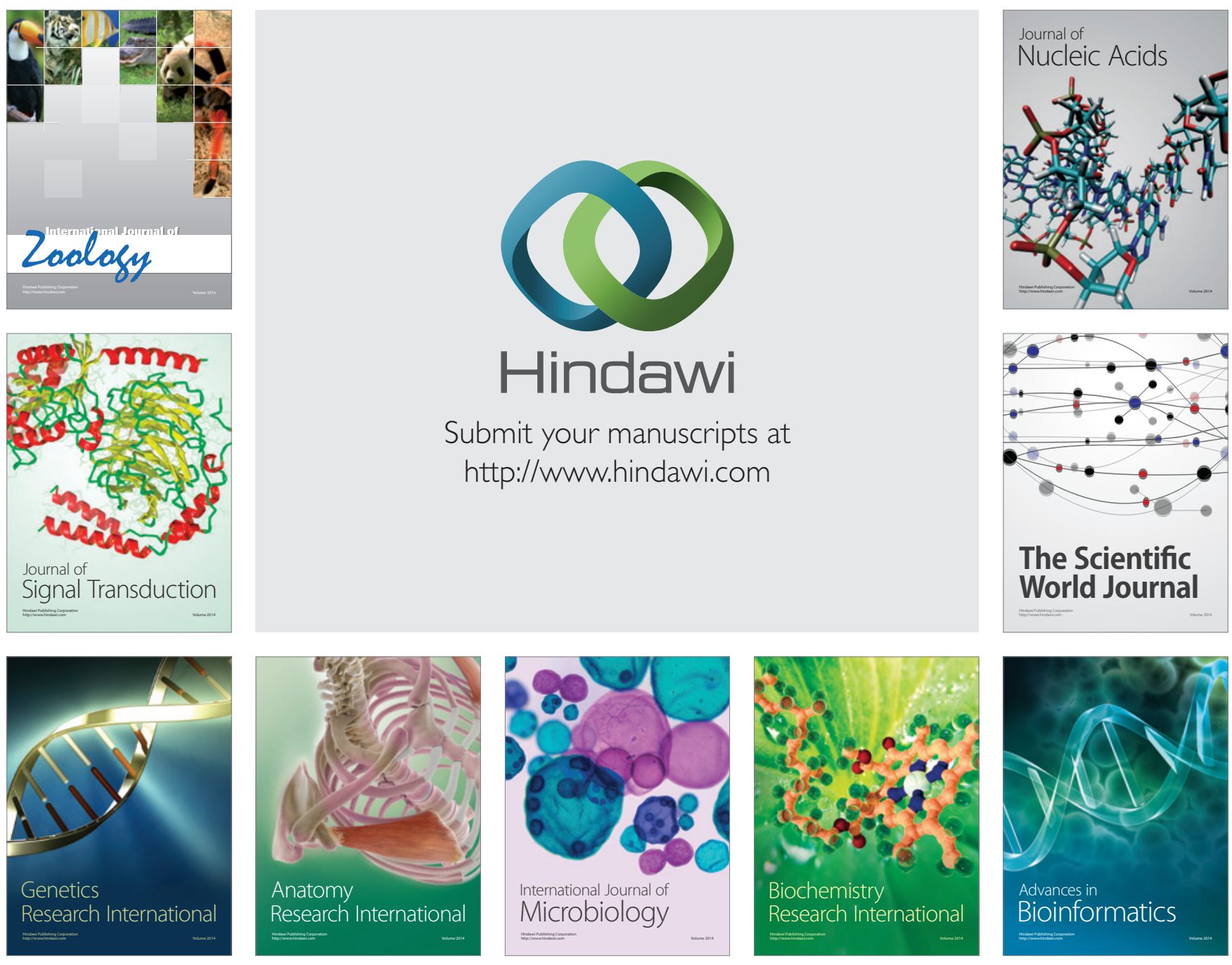

The Scientific World Journal
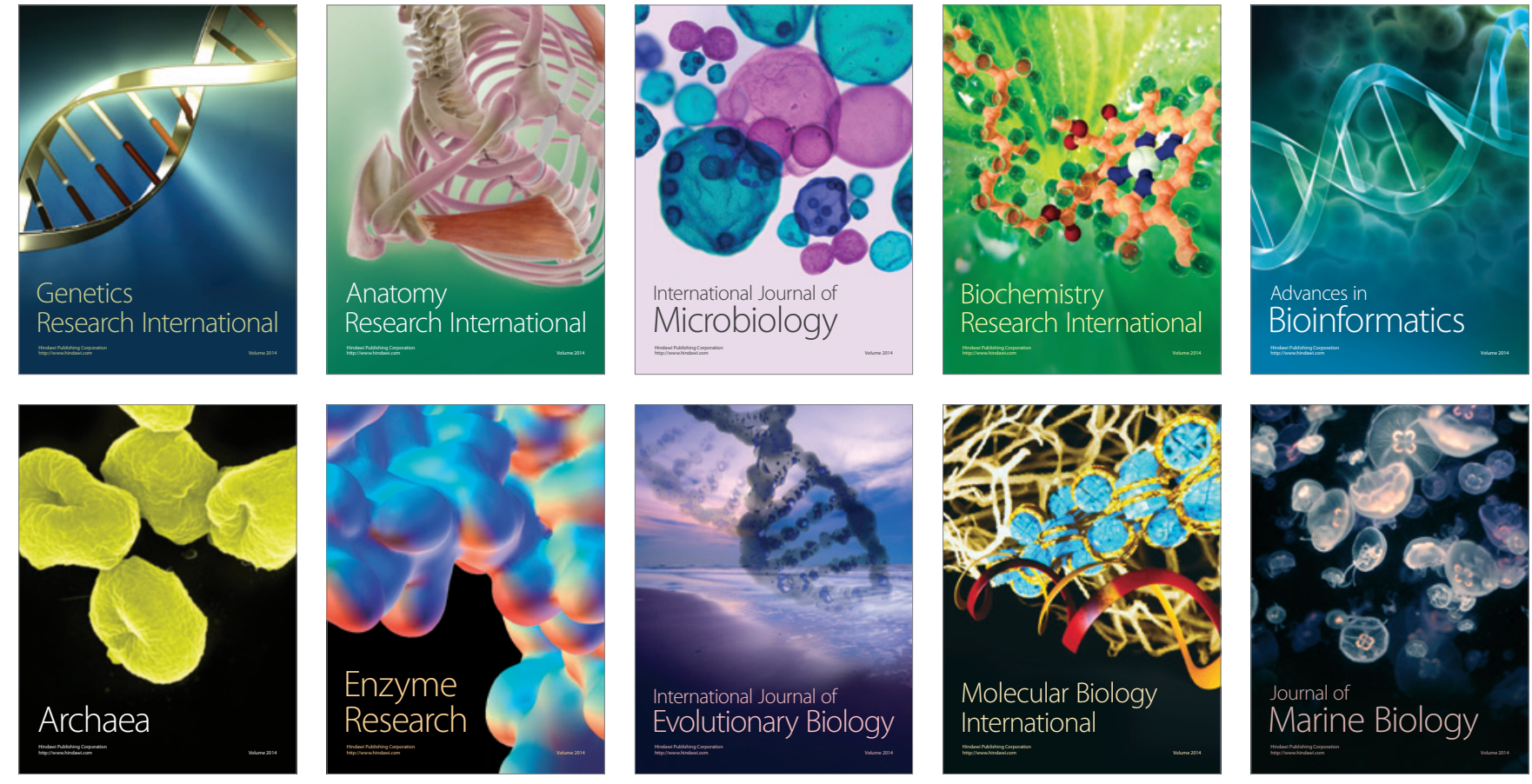